\title{
Liquid forging processing of automobile wheels
}

\author{
V.G. Trifonov, G.R. Khalikova ${ }^{\dagger}$ \\ Institute for Metals Superplasticity Problems RAS, Khalturin St. 39, 450001 Ufa \\ † gulnara.r.khalikova@gmail.com
}

\section{Жидкая штамповка автомобильных колес}

\author{
Халикова Г.Р., Трифонов В.Г. \\ Институт проблем сверхпластичности металлов РАН, ул. С.Халтурина 39, 450001 г. Уфа
}

\begin{abstract}
В работе проведена оценка возможности изготовления жидкой штамповкой автомобильных колес диаметром 17 дюймов из алюминиевых сплавов А356.2 и 6061. Проведена оптимизация режимов и разработана экспериментальная технологическая схема процесса жидкой штамповки автомобильных колес.
\end{abstract}

Ключевые слова: жидкая штамповка, алюминиевый сплав, механические свойства, автомобильное колесо

\section{Introduction}

Liquid metal (as any liquid) cannot be forged and it is almost incompressible. That is why if we speak about forging from liquid metal we mean that final forming and strengthening of a metallic parts are realized in the process of crystallization at consolidation or during plastic deformation after final crystallization when a metal is in a semi-plastic (solidliquid) or plastic state.

As compared to die casting the liquid forging performed by the scheme of reverse extrusion possesses has a number of advantages [1-3].

1. The path of metal is several times shorter than in the case of the die casting. Consequently, the loss of ductility is less and the metal can fill in the mould under lower pressures and rates.

2. At extrusion of the metal there are no conditions for air hold up since the metal is poured into an open mould forcing out the air volume equal to the full volume of the poured metal. The path of metal displacement while filling in the mould is rather short. Due to that this process occurs at rates much lower than in case of die casting. However, this time is enough for air being withdrawn from the mould.

3. At die casting it is difficult to avoid front blows and turbulence while filling in the metal normal to walls and a rod. Because of that the hydrodynamic pressure being the most important factor for processing ingots with sharp edges and packed structure is wasted without creating useful work.

At forming by extrusion there are no conditions for formation of turbulences and losses of hydrodynamic
The possibility of liquid forging of 17' automobile wheels out of the A356.2 and 6061 aluminum alloys was evaluated. The optimization of liquid forging was executed and the pilot technological process of liquid forging of automobile wheels was developed.

Keywords: liquid forging, aluminum alloy, mechanical properties, automobile wheel.

pressure connected with them, i.e. there are no causes which prevent the metal to fill fully the mould contour and even thin deep cavities. The metal moves upwards along the whole section of a casting part normally to the bed die walls without front blows.

The goal of the activities was to develop the technological process of liquid forging of 17' wheels out of the aluminum alloys A356.2 and 6061.

For developing the technological process of liquid forging of 17 ' wheels the following activities have been fulfilled:

1. Development of a design of a die tooling for liquid forging of 17 ' wheel.

2. Optimization of regimes of liquid forging.

3. Development of the pilot technological process of liquid forging and production of a pilot batch of wheels.

\section{Materials}

Liquid forging of wheels was performed by using following aluminum alloys:

- $\mathrm{A} 356.2[(6.5-7.5) \% \mathrm{Si},(0.2-0.4) \% \mathrm{Mg}, 0.15 \% \mathrm{Ti}$, $0.08 \% \mathrm{Fe}, 0.01-0.04 \% \mathrm{Sr}$, the balance $\mathrm{Al}]$;

- $6061[0.6 \% \mathrm{Si}, 0.28 \% \mathrm{Mn}, 1.0 \% \mathrm{Mg}, 0.2 \% \mathrm{Cr}$, the balance $\mathrm{All}]^{\star}$.

${ }^{\star}$ All concentrations indicated in wt. $\%$. 


\section{Results}

The influence of pressure. As compared to die casting the liquid forging increases mechanical properties. According to $[1,2,4-6]$ the increase in strength properties of silumins crystallized under pressure is conditioned by the decrease in their porosity and the change in the ratio of phases in the direction of silicon increase. Formation of homogeneous structure, refinement of phase constituents and elevated dissolution of silicon in solid $\alpha$ - solution lead to increasing ductility.

Liquid forging is usually conducted under specific pressures within the range from 400 to $1000 \mathrm{~kg} / \mathrm{cm}^{2}$, i.e. lower than deformation of metal in the plastic state by $5 \ldots 8$ times [1]. This also provides an opportunity to remove main cast defects, namely gas and shrinkage voids, and form finegrained equiaxed structure in a blank.

As the pressure and the period of holding of the poured metal under pressure increase, the deformation of the billet can be realized in the plastic state that is accompanied by a significant increase in strength and ductile properties.

Pressure is the most important factor affecting all elements of the technological process (temperature of pouring, safe durability of metal holding in the mould until pressure supply), final results of ingot consolidation and improving mechanical properties of the alloy.

Pressure in the process of crystallization contributes to structure refinement of the alloy. According to [1] the decrease in the critical size of the nuclei of crystallization ( $r$ ) can be achieved not only due to the increase in supercooling $\Delta \mathrm{T}$, but also the increase in outer pressure by $\mathrm{dP}$ :

$$
r=\frac{2 \sigma}{\Delta t} \frac{d t}{d P\left(V_{2}-V_{1}\right)},
$$

where

$\sigma \quad-$ the surface stress on center of crystallization - crystal -interface;

$\mathrm{V} 1$, V2 - the volume of solid and liquid phases, $\mathrm{t}$ - the temperature.

The value $\sigma$ also depends on pressure. Pressure in the process of crystallization of the alloy decreases the energy of phase interaction on phase interface.

The grain size also decreases due to the mechanical effect of the pressing punch on forming crystals. In the process of liquid forging separate crystals are destroyed during deformation of the skin and additional centers of crystallization are formed. This explains the formation of the zone of fine crystals in the center of the forging.

Moreover, additional nuclei's of crystallization are formed due to sluicing of solid-phase particles by the flow of nonsolidified metal when the punch intents the forging. They are also formed when mechanical pressure is applied to the crystallized and the solidified metal.

According to [7] the significant structure refinement and the change in mechanical properties occur under the increased pressure up to $2000 \mathrm{~kg} / \mathrm{cm}^{2}$. Further increase in pressure does not exert a significant influence on structure and mechanical properties of the alloy.

Taking into account the above mentioned facts the investigations relating to the influence of pressure on forming of a wheel, 17 inches in diameter, have been performed.

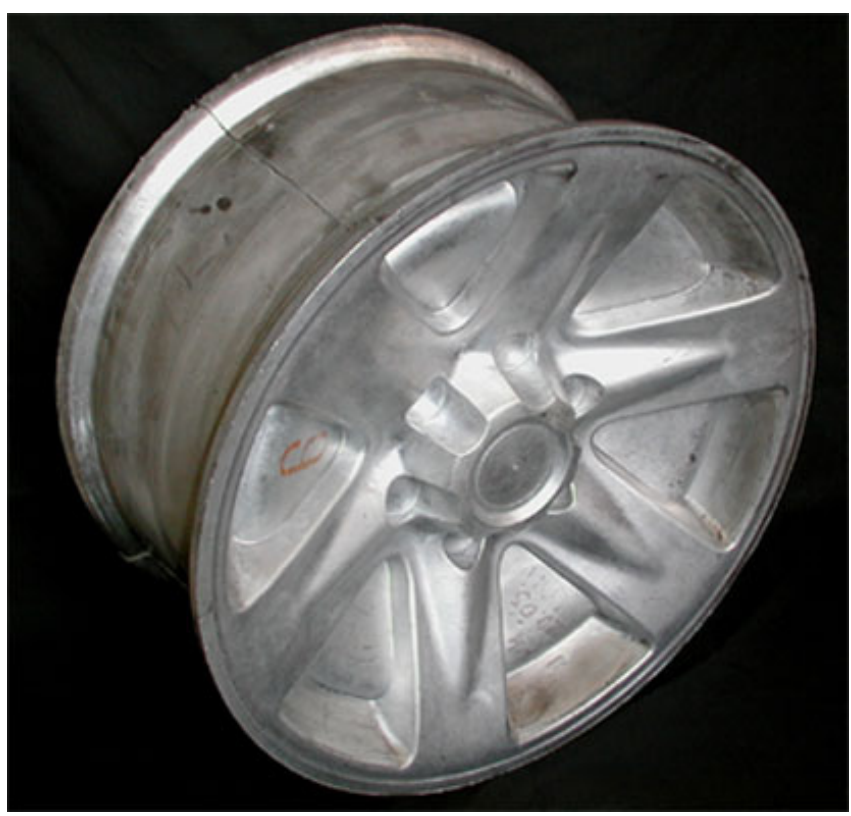

a)

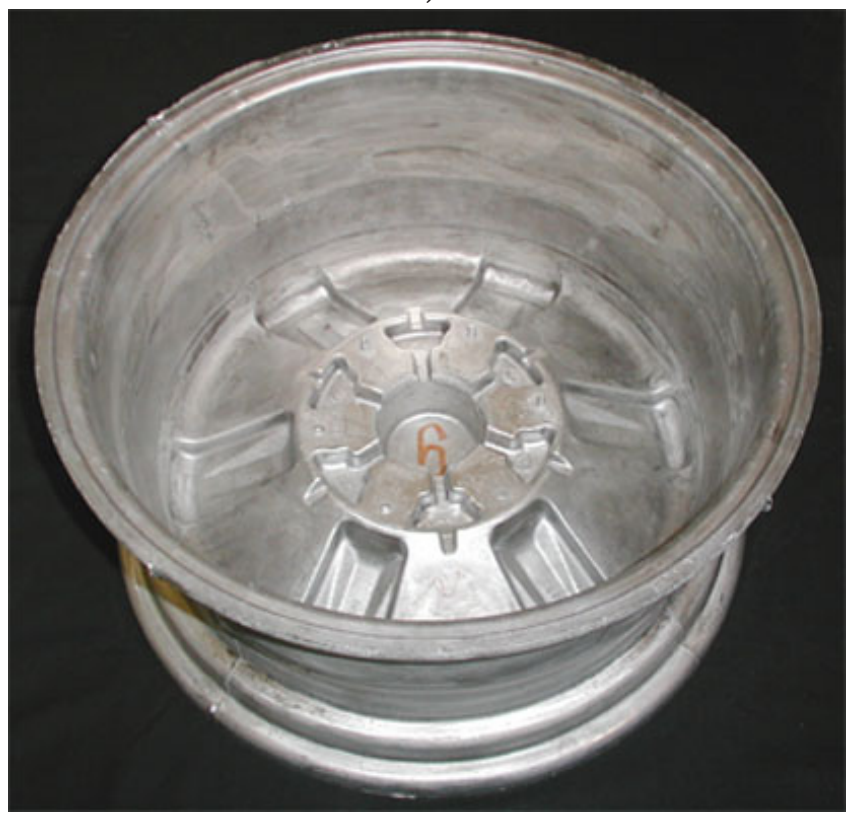

b)

Fig. 1 - View of 17' wheel processed at pressure of 630 tons.

Liquid forging has been conducted in the following regimes $[8,9]$ :

- the temperature of the melt of alloy 6061 was $790 \ldots 840^{\circ} \mathrm{C}$;

- the temperature of the melt of alloy A356.2 was $690 \ldots 730^{\circ} \mathrm{C}$;

- $\quad$ temperature of the die tooling $-260 \ldots 400^{\circ} \mathrm{C}$;

- $\quad$ pressure during forging - 30, 150, 300, 450, 540, 630 tons.

Under the load 30, 150 and 300 tons the wheels had non-formed ledges, a hub with a non-formed inner surface, cracks on the inner surface of spokes, cracks in hollows for bolts and low quality of the right side surface with a large number of small cavities.

The wheel produced under the load 440 tons had a nonformed ledge and a small shrinkage hollow on ridges of the inner hub portion, cracks on the hub and in hollows for bolts. The quality of the surface was good. 
Forging under the load of 530 tons resulted in production of the wheel with a completely formed ledge and hub and good surface quality. Cracks were observed only on the inner portion of the hub.

Liquid forging under the load 630 tons provided producing a wheel with a forming ledge and hub and good surface (fig.1). The pressure was $3.6 \mathrm{~kg} / \mathrm{mm}^{2}$.

So, the minimal pressure required for processing the 17 'wheel by the method of liquid forging is 630 tons.

Temperature of the die tooling. Influence of temperature of the die tooling on quality of wheels investigated on A356.2 alloy. According to [10] the wear of the mould resulted from its interaction with the melt depends not only on the degree of heating but mainly the duration of heating. That is why it is necessary, where possible, to reduce the time of melt being in the mould and withdraw the ingot at once after completion of the process of solidification. Prior to pouring the mould and the punch should be heated to the temperature $175 \ldots 200^{\circ} \mathrm{C}$. In the process of working the temperature of the mould should not exceed $400^{\circ} \mathrm{C}$. Pouring into the cold mould causes abrupt cooling of the metal and initiates formation of a columnar structure. The cold punch causes cooling of metal in the head portion of the blank and prevents filling of shrinkage voids. Pouring into the overheated die tooling results in its rapid wear and leads to adhering of metal to the die.

For determining the optimal temperature of the die tooling during liquid forging of 17' wheels the following investigations have been performed;

Liquid forging was performed at temperatures 420,380 , $340,300,260^{\circ} \mathrm{C}$. The temperature of the melting alloy was $705 \ldots 714^{\circ} \mathrm{C}$, the load -630 tons. Two wheels were produced in each regime, except $t=300^{\circ} \mathrm{C}$ by which only one wheel was produced.

The wheels produced at the temperatures 420 and $380^{\circ} \mathrm{C}$ had no defects and good surface quality. The decrease in the temperature of the die tooling to 340,300 and $260^{\circ} \mathrm{C}$ led to formation of defects on the ledge, cracks on the inner surface of the hub. So, the optimal temperature of the die tooling for liquid forging is $380 \ldots 420^{\circ} \mathrm{C}$.

The time between pouring of metal and the onset of forging. The influence of the time required for punch supply on forming of a wheel has been studied on A356.2 alloy. It has been revealed that the less this time the more qualitative the wheel processed. For the press PA2638 the minimal time was 11 seconds. The minimal time of punch supply equal to 11 seconds is optimal for the temperature of the melting alloy below $710^{\circ} \mathrm{C}$. The increase in the time required for supplying the punch and beginning of forging results in formation of cracks on the hub of the wheel. For higher temperature its increase is admissible.

Microstructural analysis. The analysis of microstruc-

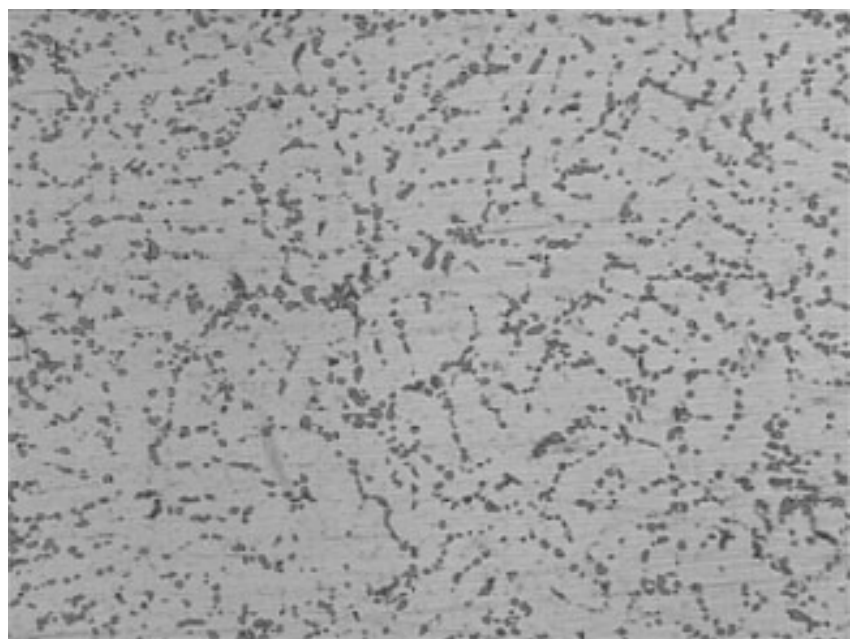

a)

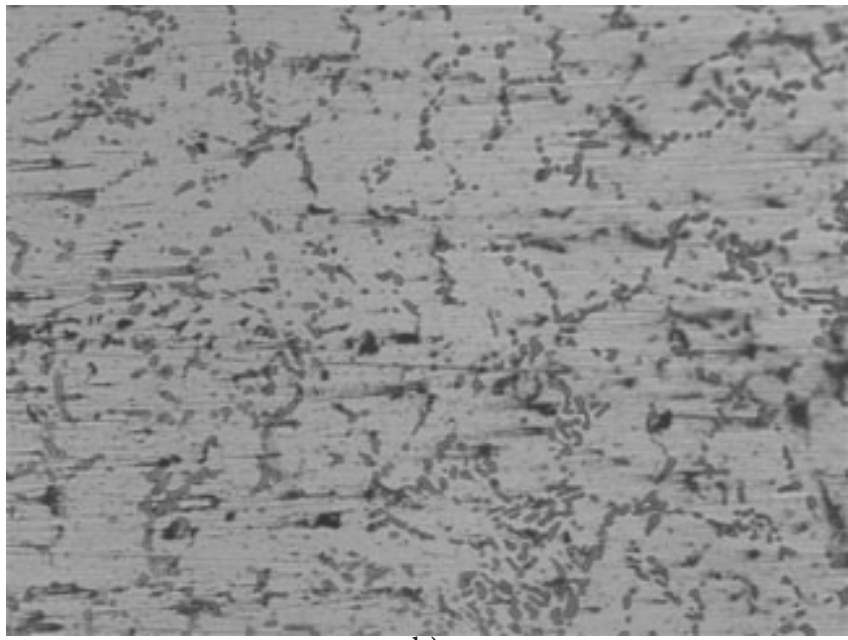

b)

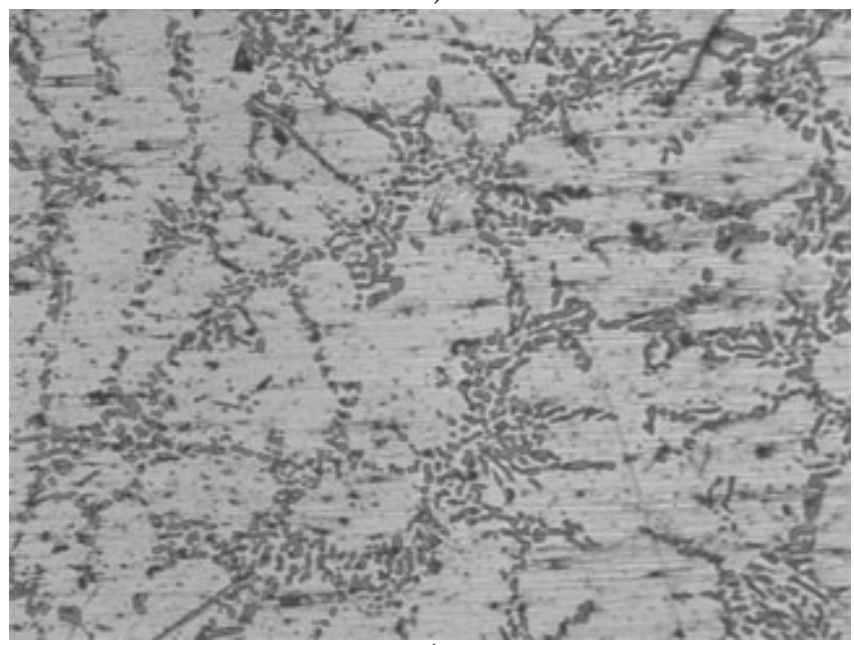

c)

Fig. 2. Microstructure of the alloy A356.2 of the 17' wheel: rim (a), spoke (b) and hub (c) $(\times 150)$.

Mechanical properties of the wheels.

Table 1.

\begin{tabular}{|c|c|c|c|c|c|}
\hline Alloy & Item & Tensile $\left(\mathrm{kg} / \mathrm{mm}^{2}\right)$ & Yield $\left(\mathrm{kg} / \mathrm{mm}^{2}\right)$ & Elongation (\%) & Hardness (HB) \\
\hline \multirow{4}{*}{ A356.2 } & Spoke & 29.9 & 22.9 & 7.1 & 94.1 \\
\cline { 2 - 6 } & Rim & 29.8 & 21.6 & 9.8 & 95.6 \\
\cline { 2 - 6 } & Hub & 29.8 & 21.2 & 10.4 & 96.3 \\
\hline \multirow{3}{*}{6061} & Spoke & 26.5 & - & 0.2 & 95.0 \\
\cline { 2 - 6 } & Rim & 26.0 & 25.0 & 0.9 & 95.0 \\
\cline { 2 - 6 } & Hub & 28.0 & 26.5 & 2.1 & 95.0 \\
\hline
\end{tabular}


ture of samples cut out according to the scheme in fig. 2 has shown that the microstructure of the wheels is uniform within the whole interior.

Mechanical properties. Average values of mechanical properties of samples are shown in Table 1.

\section{Conclusions}

1. The developed technological process for liquid forging of 17 ' wheels out of the aluminum alloys 6061 and A356.2, provides the high level of mechanical properties. The optimal temperature of the mould was $380 \ldots 420^{\circ} \mathrm{C}$. This causes the replacement of the material of some components by more high temperature materials.

2. The optimal temperature of the melt of alloy 6061 was $790 \ldots 800^{\circ} \mathrm{C}$. The optimal temperature of the melt of alloy A356.2 was $690 \ldots 710^{\circ} \mathrm{C}$.

\section{References}

1. A.I. Batishev. Crystallization of metals and alloys under pressure, Moscow, Metallurgy (1990) 144 (in Russian) [А.И. Батышев. Кристаллизация металлов и сплавов под давлением, М., Металлургия (1990) 144].

2. M.R. Chomashchi, A. Vikhrov. J. Mater. Proc. Technol. 101, 1 (2000).

3. G.A. Chadwick, T.M. Yue. Met. Mater. 5 (1), 6 (1989).

4. Dong J.X., Karnezis P.A., Durrant G., Cantor B. Metall. Mater. Trans. A. 30, 1341 (1999).

5. Lee K., Kwon Y.N., Lee S. J. Alloys Comp. 461, 532 (2008).

6. Lee Ch.D. Mater.Sci.Eng.A 488, 296 (2008).

7. T.N. Lipchin. Structure and properties of nonferrous alloys crystallized under pressure, Moskva, Metallurgiya (1994) 128 (in Russian) [Т.Н. Липчин. Структура и свойства цветных сплавов, затвердевших под давлением, М., Металлургия (1994) 128].

8. E.A. Klimov, V.G. Trifonov. Casting processes. 1, 70 (2004) (in Russian) [Е.А. Климов, В.Г. Трифонов. Процессы литья. 1, 70 (2004).

9. Patent \# 2233728 (in Russian) [Патент № 2233728].

10. B.M. Plyadskiy. Forging from Liquid Metal, M-L., Mechanical engineering (1964) 316 (in Russian) [B.M. Плятский. Штамповка из жидкого металла / B.M. Плятский. - М-Л., Машиностроение (1964) 316] . 